\title{
Omnibus Law in Indonesia: A Comparison to the United States and Ireland
}

\author{
Bayu Dwi Anggono \\ University of Jember, Indonesia \\ bayu_fhunej@yahoo.co.id
}

\author{
Fahmi Ramadhan Firdaus \\ University of Indonesia, Indonesia \\ fhmiramadhan@gmail.com
}

\begin{abstract}
Recently, omnibus law has become a critical discourse in Indonesia, both academically and practically. This discourse emerges from the relatively fast drafting and ratification of the Job Creation Law. This law's formation uses the omnibus law method because it contains many laws' substance into one law. One of Indonesia's fundamental issues is the absence of rules, methods, and techniques for forming the omnibus law. On the other hand, the techniques and methods of forming these omnibus laws have been practiced in various countries to accelerate the legislative process and organize regulations. However, public participation becomes one of the fundamental shortcomings to draft the legislation under omnibus law. This article aims to review and compare the omnibus law concept applied in selected countries, referencing the United States and Ireland as the model. This article also analyzes how to form the ideal omnibus law by learning from the omnibus law application in other countries that have successfully implemented it first. This study finds that omnibus laws in the United States and Ireland contribute to ushering hyperregulation symptoms that are vulnerable and hamper economic development. The above comparison needs to be adjusted to the Indonesian context to enact the omnibus law.
\end{abstract}

KEYWORDS: Omnibus Law, Indonesian Law, Comparative Omnibus Law.

Copyright $\odot 2020$ by Author(s)

This work is licensed under a Creative Commons Attribution-ShareAlike 4.0 International License. All writings published in this journal are personal views of the authors and do not represent the views of this journal and the author's affiliated institutions.

\section{HOW TO CITE:}

Anggono, Bayu Dwi \& Fahmi Ramadhan Firdaus. "Omnibus Law in Indonesia: A Comparison to the United States and Ireland" (2020) 7:3 Lentera Hukum 319-336.

Submitted: September 29, 2020 Revised: November 12, 2020 Accepted: November 23, 2020 


\section{INTRODUCTION}

The statutory legislation is an essential element in a modern democratic state and the rule of law. Statutory regulation does not only contain legal principles and norms but also philosophical content that significantly impacts democracy, welfare, and social justice. ${ }^{1}$ As a sub-system of a democratic rule of law, the legislation aims to regulate and provide an alternative, including the Government's current challenges. The legislation is an objective legal product because in the process of making and drafting techniques comply with the principles of law (rechtsbeginsel) by the people's representative institutions. ${ }^{2}$ On the other hand, the potential for disharmony of laws and regulations is an issue that is difficult to avoid. Richard Susskind calls it a phenomenon of hyperregulations. ${ }^{3}$ Susskind asserts that hyper-regulation is more about too many laws given our current methods of managing it. ${ }^{4}$ Hyper-regulation causes the law to become increasingly remote and irrelevant because many regulations are not implemented and enforced effectively. It is also complained by President Joko Widodo. Legislation in Indonesia is becoming a hyper-regulation so that it overlaps. As a result, the bureaucracy's implementation became convoluted and created investment uncertainty, thus hampering the program for his administration's first period. The 4th National Conference on Constitutional Law in Jember from 10 to 13 November 2017 recommended streamlining regulations in Indonesia to evaluate the number of regulations in various ministries and state institutions. ${ }^{5}$

There are three main steps as the recommendations for this problem. First, consistency and orderly drafting of laws and regulations that are simplified to be put forward. Second, the harmonization of central and regional policies needs to be accomplished. Third, it is necessary to simplify regulations to make them more targeted. Overcoming this overlapping regulation is an arduous one as it tries to simplify existing legal problems as the President's agenda. ${ }^{6}$ From the first period's experience, in his

1 Maria Farida Indrati, Ilmu Perundang-Undangan: Jenis, Fungsi, dan Materi Muatan (Kanisius, 2007) at 56.

2 Bayu Dwi Anggono, Perkembangan Jenis, Hierarki dan Materi Muatan Peraturan Perundang-undangan: Permasalahan dan Solusi (Konstitusi Press, 2018) at 44.

3 Richard E Susskind, The Susskind Interviews: Legal Experts in Changing Times (Sweet \& Maxwell, 2005) at 117.

4 Ibid.

5 Kompas Cyber Media, "Rekomendasi Jember untuk Penataan 'Obesitas Regulasi' di Indonesia," online: 〈https://nasional.kompas.com/read/2017/11/12/17412311/rekomendasi-jember-untuk-penataanobesitas-regulasi-di-indonesia>.

6 Agnes Fitryantica, "Harmonisasi Peraturan Perundang-Undangan Indonesia Melalui Konsep Omnibus Law" (2019) 6:3 Gema Keadilan 300-316 at 304. One of the reasons is the lack of investment entering Indonesia due to legal uncertainty. R A S Hernawati \& Joko Trio Suroso, "Kepastian Hukum dalam Hukum Investasi di Indonesia Melalui Omnibus Law" (2020) 4:1 Jurnal Ilmiah Manajemen, Ekonomi, \& Akuntansi 392-408 at 401. According to the Doing Business in Asia report, Indonesia is listed as one of Asia's countries whose legal system and laws and regulations are considered highly bureaucratic and corrupt by local and foreign investors. Doing Business, "Doing Business 2020" online: 〈https://www.doingbusiness.org/ en/reports/global-reports/doing-business-2020>. On the other hand, data on the ease of doing business by the World Bank in 2018 proves that Indonesia can only be ranked 73 with a total score of 67.96 points. Republika, "Peringkat Kemudahan Bisnis di Indonesia Belum Naik" (24 October 2019), online: 〈https://republika.co.id/share/pzv8gg383〉. Indonesia is far behind other countries such as Vietnam 
inauguration speech for the second term of his administration, President Joko Widodo chose the omnibus law as an alternative to attract more investors. ${ }^{7}$

The Government and the House in drafting laws under the omnibus law method have pros and cons. Vietnam has experienced a similar problem because it reflected overlapping regulations and a lengthy legislative procedure to revise a statutory regulation. Vietnam can implement the omnibus law considering that there are no laws and regulations that prohibit it. ${ }^{8}$ As Vietnam becomes the emerging country to take this pathway, Vietnam is excluded from the comparison. Instead, this paper compares how the omnibus law method successfully addresses hyper-regulation in the United States and Ireland. Compared to other countries that have previously applied the omnibus law, Indonesia can take some lessons for its regulatory and practical inputs. The omnibus law in Indonesia is relatively new, like Vietnam, which still needs further comparison.

On the other hand, Patrick Keyzer, Professor of Law from La Trobe University, said that omnibus law has a critical problem. This is due to the difficulty of drafting a bill, limiting the opportunity to provide input, supervision, and consultation. Also, the uneasy implementation will add to the increasingly complex regulations. If many regulations are prepared with new drafts, the process should take a long time. Instead, omnibus law needs a simultaneous way under one law, and it only takes a few months. In drafting it, to be sure, it needs academic preparation. While on the other hand, the fast-track drafting process results in aspiring and accommodating public interests? This discussion remains underway. ${ }^{9}$ Against the omnibus law, Maria Farida Indrati, Indonesian Legislation Expert, delivered several suggestions. First, any legislation should be based on the legislative drafting principles that deserve (beginselen van behoorlijke regelgeving) and based on a philosophical foundation, juridical and sociological, different from each legislation. Second, regarding the existence of various laws, some of which are repealed and placed in the omnibus law, because each law and regulating different content also regulate different subjects (adressat). ${ }^{10}$

68.36 in the 69th place, Singapore in the 2nd place with a score of 85.24. World Bank, "The World Bank DataBank" (2018). Indonesia is below Malaysia and Thailand with 80.60 and 78.45, respectively. On the other hand, the Global Competitiveness Report in 2019 placed Indonesia in 50th place in competitiveness. It is far behind Singapore, placed in the lst place, where Malaysia and Thailand are in the 27th and 40th rankings. World Economic Forum, "World Economic Forum Reports" online: 〈https://www.weforum.org/reports/.

7 The draft formed through the omnibus law method includes the Job Creation Bill, the State Capital Bill, and the Small and Medium Enterprises (SMEs) Empowerment Bill. President Jokowi planned the three bills would become the omnibus laws. One law that simultaneously revises several laws, even dozens of laws, aimed at attracting investment to open up new jobs. Kompas Cyber Media, "Naskah Lengkap Pidato Presiden Joko Widodo dalam Pelantikan Periode 2019-2024" online: 〈https://nasional.kompas.com/jeo/naskah-lengkap-pidato-presiden-joko-widodo-dalam-pelantikanperiode-2019-2024>.

8 Fajar Kurniawan, "Problematika Pembentukan RUU Cipta Kerja Dengan Konsep Omnibus Law" (2020) 5:1 Jurnal Panorama Hukum 63-76 at 67.

9 Kanal 24, "Patrick Keyzer: Omnibus Law Menambah Kompleksitas Hukum Indonesia." online: 〈http://kanal24.co.id/read/patrick-keyzer-omnibus-law-menambah-kompleksitas-hukum-indonesia〉.

10 Maria Farida Indrati, “'Omnibus Law', UU Sapu Jagat?" online: Kompas.id 〈https://kompas.id/baca/ opini/2020/01/04/omnibus-law-uu-sapu-jagat/>. 
The problem discussed in this article is how the method of forming the omnibus law should confirm with Indonesia's legislative draftings guidelines? The first part of this paper examines the idea and implementation of the omnibus law. In the second part of this paper, a comparative perspective on the United States and Irish practices is presented. This section also analyzes the application of the omnibus law in Indonesia by reflecting on the United States and Ireland's omnibus law application. In the third part, this paper examines the prospects for omnibus law in Indonesia in the future and the extent to which it is relevant to the statutory system within the national legal system framework.

\section{METHODS}

The method used in this paper is legal research with a conceptual approach. This paper also uses a comparative approach method by comparing the United States' best practices and Ireland's experiences regarding omnibus law. Then, it provides their differences and similarities by considering its regulatory framework and practice in the respective countries. The analysis used in this study is qualitative, by studies from the laws and regulations, books, journals, and doctrines regarding laws and regulations and omnibus law.

\section{OMNIBUS LAW IN INDONESIA: A CRITICAL REFLECTION}

The term omnibus law has become a new lexicon for Indonesia, including Indonesia's new experience to draft its laws and regulations. Historically, the omnibus law was adopted from the common law legal tradition, which was later adopted by other legal systems with European Continental style such as Indonesia. This model of adopting the method between legal systems is becoming commonplace today due to globalization. Common law countries such as America, Canada, and Ireland, for example, have used this approach in drafting various laws.

\section{A. Why Does Indonesia Need Omnibus Law?}

In Indonesia, the omnibus law is the policy chosen by President Joko Widodo to address the complex laws and regulations in Indonesia. It has different meanings in various pieces of literature but has the same essence. In 1830 in the city of Paris, France, for the first time, a bus could transport goods and people at the same time to the same destination. At that time, there were no buses that could be used to carry people and goods simultaneously. In other words, goods and people were carried separately. Then, the bus was known as an omnibus. Latin American countries use the name omnibus as a 
legal term to regulate many things through a law. Therefore, the term omnibus law is also known as the law used to contain many things but is more efficient."

According to the Oxford English Dictionary, the word omnibus means a volume containing several books previously published separately. Literally, omnibus comes from the Latin omnis, which means every or all, or preferably all, every, the whole, of every kind. In Black's Law Dictionary 10th, the term omnibus bill is defined as a solitary bill containing different particular issues, drafted to constrain the leader to acknowledge all the random minor arrangements or blackball the significant arrangement. Omnibus law is also understood to manage all propositions identifying with a specific subject, such as an omnibus judgeship charge covering all recommendations for new judgeships or an omnibus wrongdoing charge managing specific subject example, new violations, and awards to states for wrongdoing control. Maria Farida Indrati defines the omnibus law as a new law regulating kinds of substances and subjects to simplify various existing laws. It is not appropriate if the omnibus law is perceived as the same as the umbrella law (raamwet, baswet, moederwet). The paying law is the parent of other laws. Its position is higher than its children's derivative laws. This umbrella law delegates various further regulations by delegation to other laws. ${ }^{12}$ Against the omnibus law, Jimly Asshiddiqie reflects many substantive laws or all substantive laws, including laws related directly or indirectly. This practice is certainly not prevalent in the Civil Law tradition. However, it remains considered good practice and practiced today as omnibus law. ${ }^{13}$ Therefore, the omnibus law is a new law that contains or regulates various kinds of materials and subjects that aim to simplify various laws that are still in force.

The Official Academic Paper on the Job Creation Bill defines the omnibus law as a drafting law method. It is mostly practiced in the common law or Anglo-Saxon system (such as the United States, Canada, United Kingdom, and the Philippines). This process is called omnibus legislation, and the product is called omnibus law. The word omnibus comes from Latin, which means for everything. ${ }^{14}$ Duhaime Legal Dictionary defines omnibus law as a draft law before a legislature. It contains more than one substantive matter or several minor matters combined into one bill, ostensibly for the sake of convenience. ${ }^{15}$ In the Merriam Webster legal dictionary, omnibus law comes from the omnibus bill, namely laws covering various issues or themes. Through the omnibus law, legislators can revise many rules at once. ${ }^{16}$

1l Ministerial Coordinator for Political, Legal, and Security Affairs Moh. Mahfud MD in his speech at the Law \& Regulation Outlook 2020 event at the Shangri-La Hotel, Central Jakarta, (Wednesday 22 January 2020).

12 Maria Farida Indrati, supra note 10.

13 Jimly School, "UU Omnibus Law Penyederhanaan Legislasi dan Kodifikasi Administratif" online: <https:/www.jimlyschool.com/baca/34/uu-omnibus-omnibus-law-penyederhanaan-legislasi-dankodifikasiadministratif).

14 House of Representative, Academic Manuscript of the Job Creation Bill (Secretariat, 2020) at 24

15 Duhaime, "Omnibus Bill Definition" online: 〈http://www.duhaime.org/LegalDictionary/O/Omnibus Bill.aspx>.

16 Sindonews, "Serikat PekerjaTolak Omnibus Law" online: ‘https://nasional.sindonews.com/berita/1509229/ 16/serikat-pekerjatolak-omnibus-law». 
Sofyan Djalil, the Minister of Agrarian Affairs and Spatial Planning, argues the omnibus law is a step to issue a law that improves many laws considered overlapping and hamper business. With the issuance of a law to improve the number of laws, it is expected that this method will solve problems in the economic sector. It is because many laws cannot be accelerated. After all, they are still valid and regulated and can conflict with each other. ${ }^{17}$ From some of the explanations above, the omnibus law has several characteristics. It consists of multiple sectors or many sectors with the same theme or even different and has many articles because many sectors are covered, unlike ordinary laws. It is made without being bound by other regulations and negating or partially revoking all other laws and regulations.

\section{B. Advantages of the Omnibus Law}

There are several reasons why legislators in various countries choose legislation techniques using the omnibus law method. One of the important reasons is the ease with which legislators can reach an agreement or approval of new draft legislation. Besides, this technique avoids political deadlock due to the complexity of the omnibus law's substance. Differences in interests can be compromised with each member of the Parliament to accommodate the desired substance. ${ }^{18}$

Canadian political scientist Louis Massicotte says that omnibus bills, when introduced in law-making bodies where individuals are free to cast a ballot as they wish, may incorporate the result of complex exchanges between self-intrigued officials. ${ }^{19}$ Louis Massicotte then explained the two advantages of the omnibus law in the formation of laws. First, the omnibus law method is more efficient. It shortens the legislative process because there is no need to revise many laws. Instead, with this method, the formation of laws is sufficient to pass a single draft law whose substance contains many revised material from various laws. By only going through one law, it contains many substantial revisions from various laws. It reduces the law-making duration. Then, legislators' exhausted debate against each law can be minimized. Second, this method creates a relationship between the opposition party and the majority in the parliament, which usually adheres to the win and lose principle in deliberating draft laws. Through the omnibus law method, both of them have an opportunity. Many substances in the omnibus law that trigger rejection of a law's entire contents by the opposition party can be avoided. This is because the opposition party has the option not to agree on one substance and the opportunity to agree on another substance. ${ }^{20}$

17 Hukumonline, "Menelusuri Asal-Usul Konsep Omnibus Law" online: 〈https://www.hukumonline.com/ berita/baca/lt5e2cle4de97la/menelusuri-asal-usul-konsep-omnibus-law〉.

18 Bayu Dwi Anggono, "Omnibus Law sebagai Teknik Pembentukan Undang-Undang: Peluang Adopsi dan Tantangannya dalam Sistem Perundang-undangan Indonesia” (2020) 9:1 Jurnal Rechts Vinding: Media Pembinaan Hukum Nasional 17 at 24.

19 Louis Massicotte, "Omnibus Bills in Theory and Practice" (2013) 36:1 Canadian Parliamentary Review 13-17 at 15 .

20 Massicotte, supra note 19. 
A Gluck, AJ O'Connell, and R Po explained that omnibus law has its complexities. $^{21}$ However, this method can accommodate many stakeholders in parliament. $^{22}$ The next benefit of the omnibus law is to unite various interests in Parliament. Omnibus legislation often comprises "mini-bills" -separate pieces of legislation, possibly separate points inside a solitary subject, drawn by different advisory groups and connected..$^{23}$

The implementation of the omnibus law raises several implications. First, resolve conflicts of laws and regulations quickly, effectively, and efficiently. Second, harmonizing government policies, both at the central and regional levels, supports the investment climate. Third, licensing management is more integrated, efficient, and effective. Fourth, able to break the bureaucratic chain that is too long. Fifth, improving the coordination relationship between related agencies because it has been regulated in an integrated policy. Sixth, the creation of legal certainty and legal protection for policymakers. ${ }^{24}$

\section{Disadvantages of the Omnibus Law}

The omnibus law also has several weaknesses that need to be taken into account. Among these weaknesses, it is difficult for the parliament to discuss legislation, as Adam M Dodek argues. Omnibus bills hinder parliamentarians to appropriately investigate a bill's substance and exercise their function in considering the legislature answerable. ${ }^{25}$ American journalist Lorne Gunter emphasizes that the omnibus law is anti-democratic because, in the process of its formation, it limits both debate and control over its application. Moreover, the omnibus law in the past has often been used to pass controversial regulations. ${ }^{26}$ Therefore, the omnibus law can be misused to benefit certain interest groups and harm the wider community. Examples of the controversial omnibus law are Bill C-94, created by Prime Minister Trudeau, and the 1982 Energy Security Act, which angered the Conservative Progressive, the opposition. ${ }^{27}$

For countries adopting a veto system, such as the United States, the omnibus law hampers the President to use the veto right in rejecting laws approved by Congress. Given that the President's veto system is in the form of rejection of the entire law, the parliament can use the omnibus law, which has much content, as a shield. The President does not overturn it through veto rights. On the other hand, some material in the President's interest can be accommodated in the omnibus law to think twice about

21 Abbe R Gluck, Anne Joseph O'Connell \& Rosa Po, "Unorthodox Law-making, Unorthodox Rulemaking" (2015) 115 Colum L Rev 1789 at 1803.

22 Ibid.

23 Ibid.

24 Firman Freaddy Busroh, "Konseptualisasi Omnibus Law dalam Menyelesaikan Permasalahan Regulasi Pertanahan" (2017) 10:2 Arena Hukum 227-250 at 247.

25 Massicotte, supra note 19 at 16.

26 Torontosun, "Omnibus Bills in Hill History" online: 〈https://torontosun.com/2012/06/18/ omnibus-bills-inhill-historys.

27 Massicotte, supra note 19 at 13. 
canceling the entire law. ${ }^{28}$ Thus, it concludes section concludes some weaknesses of the omnibus law. First, pragmatic and less democratic. Second, the lack of space for public participation does not follow the concept of a democratic rule of law. Third, reduce the accuracy and caution in its formation because there are many regulated and multisubject provisions. Fourth, the potential to go beyond constitutional provisions due to the lack of participation and the discussion. ${ }^{29}$

\section{THE PRACTICE OF OMNIBUS LAW IN SELECTED COUNTRIES}

\section{A. Omnibus Law in the United States}

Before discussing the U.S omnibus law application, it is essential to outline legislation formation in the United States first. Based on the U.S. Constitution Article I Section I, the formation of laws is under the U.S. Congress's power, consisting of the Senate and the House of Representatives. The United States' legislative function is only held by two Congress chambers, namely the Senate and the House of Representatives. The U.S. parliament structure is bicameral. The two powers have equal power with each other or so-called strong bicameral. Thus, each law must be approved in both chambers. Article 1 Section 7 Number 2 of the U.S. Constitution outlines each bill that will pass the House and the Senate. Under the steady gaze, it becomes the law, introduced to the U.S. President. If he favors, he will sign it. However, on the off chance that not he will restore it, it will have started with his issue with the House, who will enter the protest everywhere on their diary and continue to think about it. On the off chance that after much thought, two-third of that House consents to pass the charge, it sent along with the complaint to another house. It will moreover be thought of. Whenever endorsed by $66 \%$ of that House, it shall become a law. In all such cases, yeas and nays shall dictate the two Houses' votes. Then, the name of the people deciding in favor of and against that bill will be entered. Whenever House separately. Suppose any Bill is not returned by the President inside multi-day (except Sunday) after it will have been introduced to him. In that case, the equivalent will be a law, like he had marked it, except if the Congress by their intermission forestall its return wherein case it will not be a law. Accordingly, every law must be approved by Congress's two chambers, namely the Senate and the House of Representatives. Before becoming a law, it must be forwarded to the President for approval. If agreed, the law will be signed. If there is no agreement, the President will return to the Senate and House of Representatives to explain the refusal or objection.

The President's rejection of a bill approved by the two chambers of the U.S. Congress is known as a veto. The veto is the constitutional authority owned by the President of the United States to pass a bill. In theory, this practice is called a "presidential veto." ${ }^{30}$ However, the U.S. President's veto can be repealed by the Senate and the House

28 Ibid.

29 Bayu Dwi Anggono, supra note 18.

30 Saldi Isra, Pergeseran Fungsi Legislasi: Menguatnya Legislasi Parlementer dalam Sistem Presidensial di Indonesia (Rajawaali press, 2011) at 88. 
through a "legislative veto." In the U.S. Constitution, this term for rejection is called "override." Overrides are carried out by the two chambers of both the Senate and the United States House of Representatives to meet 2/3 of each room's votes. If the 2/3 conditions are met, the bill becomes law. In other words, if approved by two-thirds of that House, it shall become a law.

In practice in the United States, the veto power is exercised in two ways: regular veto and pocket veto. Regular veto is the type of veto most often used by the President of the United States. This type of veto is submitted when the DPR and Senate are in session. If the President does not file an objection within 10 days while the DPR and Senate are at trial, the bill becomes lawful. Pocket Veto occurred because the 10-day deadline for filing an objection to the President coincided with the DPR and the Senate not being in session. Even if the President objects, the DPR and Senate cannot override it. With a pocket veto, a bill cannot become a law. ${ }^{31}$

In 1888, the United States used the term omnibus bill to regulate railroad distribution in the context of the omnibus law. However, the omnibus law was only implemented in the United States in 1950, namely the Omnibus Appropriations Act. ${ }^{32}$ In 1967, the United States Secretary of Justice, Pierre Trudeau, also used the same method when amending his criminal law through the "omnibus law amendment bill." In 2009, the United States introduced the Omnibus Public Land Management Act of 2009. This law designates millions of land areas in the United States as protected areas and establishes a national landscape conservation system.

This Law's formation was motivated by concerns over climate change that could threaten access to water resources. This Act also regulates the content of recovery acts expected to generate investments that provide benefits for protecting and restoring ecosystems in the United States. ${ }^{33}$ Against the Omnibus Public Land Management Act of 2009, in its form, it is a law that contains more than one substantive material that was previously separated in several acts. ${ }^{34}$

According to Krutz, two approaches explain the emergence of the omnibus law, which impacts institutional changes. The two approaches are at the micro and macro level. At the micro-level, it is the individual's will to build a coalition at the Congress. At the same time, at the macro level, some obstacles arise in the Congress environment. It is vital to pay attention to the legislative process at the micro-level so that a draft law becomes law. Two things must be ensured: the coalition in Congress to pass legislation and a veto from the President must be avoided. ${ }^{35}$

$31 \quad$ Ibid at 89 .

32 Ninis Chairunnisa, "Pengamat Hukum: Banyak Negara Kapok Pakai Omnibus Law" online: Tempo 〈https://nasional.tempo.co/read/131081l/pengamat-hukum-banyak-negara-kapok-pakai-omnibuslaw>.

33 New York Times, 'Obama Signs The Omnibus Public Lands Management Act of 2009' online: 〈https://www.nytimes.com/2009/03/30/us/politics/30lands-text.html〉.

34 Ima Mayasari, "Menggagas Omnibus Law" online: kumparan 〈https://kumparan.com/dr-ima-mayasari-mh/menggagas-omnibus-law-1542018891459839175>.

35 Glen Stuart Krutz, "Explaining Institutional Change: The Rise and Impact of Omnibus Legislating" (2000) at 20. 
The main characteristic of the omnibus law in the United States is that it helps parliament members build consensus. This is because every parliament member has the right to attach his proposed bill to the omnibus law. The implementation of the omnibus law is more inclined to political style or motive to smooth the passing of a bill into law. ${ }^{36}$

The application of the omnibus law method in the United States has also been successfully implemented in several states. This is because it is guided by the concept of a single subject clause (single-theme law). As a reference, we can see in the constitution of one of the United States, Minnesota, in Article 4 Section 17 Constitution of The State of Minnesota states: Laws to grasp just one subject. No law will grasp more than one subject, which will be stated in its title. Minnesota is different. California strictly limits the implementation of the omnibus law. California's Constitution in Article 4 Section 24 states that each Act will grasp yet one subject, which will be stated in its title. Suppose any subject will be accommodated in an Act but not outlined in its title. In that case, such Act will be void just as to such a significant amount as not be stated in its title.

\section{B. Omnibus Law in Ireland}

In Ireland, the power to make laws is the Irish Parliament's responsibility or the House of Oireachtas. Dáil Éireann, as the second chamber, has a significant role in the legislation because it directly elects it. All proposed legislation was introduced to Oireachtas as Bills. When the Government wanted to propose a law, the Cabinet approved the draft law. The relevant Ministers took it to Oireachtas. Opposition parties or Members can also propose laws. ${ }^{37}$ Before it can be passed, the bill must be passed by Dáil Éireann and Seanad Éireann as the first chamber. To be passed, a bill must go through several different stages in each room. There are six stages or processes in the formation of legislation in Ireland. The first is the stage of the initiation of the bill. The second stage is a discussion of the general principles of a draft law. The third stage is the committee's examination of the draft bill by section, following the possibility of changes. The fourth stage, namely the report, which is a change in the bill's substance at the committee stage, can then be considered at this stage. The fifth stage is the endorsement or approval that both chambers must agree on. The last stage is the stage of enactment. ${ }^{38}$

Like other countries that have successfully adopted the omnibus law, Ireland has succeeded in streamlining legislation through the omnibus law as more than 18,000 legislation has been streamlined successfully. Ireland was able to abolish 3,225 laws in 2008. This achievement is considered the world record for the most practice of omnibus law. ${ }^{39}$ In early 2019, the Irish Government drafted an omnibus bill called Consequential

36 Vincent Suriadinata, "Penyusunan Undang-Undang di Bidang Investasi: Kajian Pembentukan Omnibus Law di Indonesia” (2019) 4:1 Refleksi Hukum: Jurnal Ilmu Hukum 115-132 at 125.

37 Houses of the Oireachtas, "Bills \& Acts of the Oireachtas - Houses of the Oireachtas," online: 〈https:// www.oireachtas.ie/en/bills'.

38 Houses of the Oireachtas, "Houses of the Oireachtas - How laws are made - Houses of the Oireachtas," online: 〈https:/www.oireachtas.ie/en/visit-and-learn/how-parliament-works/how-laws-are-made〉.

39 Detik News, "Selain Indonesia, Negara-negara Ini Juga Terapkan Omnibus Law" online: detiknews 〈https://news.detik.com/berita/d-4868547/selain-indonesia-negara-negara-ini-juga-terapkanomnibus-law〉. 
Provisions Bill 2019 for the Withdrawal of The United Kingdom Without a Deal. The Omnibus Bill will take effect if Britain leaves the European Union without an agreement. Ireland's Deputy Prime Minister, Simon Coveney, said a no-deal Brexit would cause widespread damage. The Omnibus Bill is designed to support businesses and jobs affected by the no-deal Brexit and secure sustainable access to essential services and products across the Irish border. The omnibus bill allows the Irish Government to mitigate some of the worst effects of a non-existent Brexit deal by protecting citizens' rights, security and facilitating extra support for vulnerable businesses and entrepreneurs. The proposed omnibus bill covers a wide range of areas. It focuses on protecting Irish citizens' rights, supporting business and work, health care, transportation, education, and energy. ${ }^{40}$

\section{Omnibus Law in Indonesia: Toward A New Alternative}

The regulatory structuring program has become President Joko Widodo's priority program in the first term of his administration. However, until the end of the first period, various efforts to organize regulations had not yet achieved the expected results. The Center for Law and Policy Studies noted several tasks in the current second period. These tasks, starting from the increasing number of regulatory regulations, the overlapping of the substance of the laws and regulations, the minimum level of public participation in the process of forming laws and regulations, and the discourse on institutional reform to overcome regulatory structuring, has not been resolved. ${ }^{41}$ In 2019, the number of regulations in Indonesia reached 42,996. In the form of 8,414 central regulations, 14,453 ministerial regulations, 4,164 regulations from non-ministerial government agencies, and 15,965 regional regulations. ${ }^{42}$ This amount is considered too fat in supporting the running of the Government bureaucracy.

Given omnibus laws in the United States and Ireland, the Government needs to take legal breakthroughs to improve it. The omnibus law is a concept adopted in four draft laws, all of which are government initiatives. Bills adhere to the omnibus law concept, namely the Bill on Job Creation, the Bill on Taxation, and the State Capital bill. The Job Creation Bill itself has 11 regulatory clusters, and by the end of 2020, it was successfully passed into law. The application of the omnibus law method in the formation of laws in Indonesia aims to pursue three benefits. First, eliminating the overlap between laws and regulations. Second, efficiency in the process of changing or revoking statutory regulations. Third, eliminating sectoral egos contained in various laws and regulations. ${ }^{43}$

40 Chronicle, "Ireland publishes omnibus bill of emergency laws in case of no-deal Brexit" online: 〈https://www. chronicle.gi/ireland-publishes-omnibus-bill-emergency-laws-case-no-deal-brexit/>.

41 Hukumonline, "Lima Langkah Penataan Regulasi untuk Pemerintahan Jokowi Jilid II" online: 〈https:/www.hukumonline.com/berita/baca/lt5db95c405cce2/lima-langkah-penataan-regulasiuntuk-pemerintahan-jokowi-jilid-ii/>.

42 Media Indonesia, "Obesitas Regulasi" online: 〈https://mediaindonesia.com/podiums/detail_podiums/ 1671-obesitas-regulasi>.

43 Cabinet Secretariat, "RUU Omnibus Law: Upaya Perkuat Perekonomian Nasional melalui Penciptaan Lapangan Kerja dan Fasilitas Perpajakan", online: 〈https://setkab.go.id/ruu-omnibus-law-upaya-perkuat-per ekonomian-nasional-melalui-penciptaan-lapangan-kerja-dan-fasilitas-perpajakan/>. 
According to Indonesia's legislation, the position of laws using the omnibus law method has not been explicitly regulated. As described earlier, the law resulting from omnibus law is a tradition from the common law system, not Indonesia's civil law system. The omnibus law method can act as umbrella laws because it sets a comprehensive regulation. Its umbrella law has higher powers over others. However, in Indonesia's legislation, the umbrella law is not adopted because all statutory laws have equal positions. When it comes to umbrella law, its type and hierarchy must be clearly defined. Of course, efforts to clarify it must be regulated in the Legislative Draftings Law, through the amendment or replacement of the current Legislative Draftings Law.

Although less familiar in Indonesia, the concept of Omnibus has been used in two previous laws. First, Law No. 9 of 2017 which repeals Articles 35 (2) and 35A of the Law on General Provisions and Procedures of Taxation, Articles 40 and 41 of the Law on Banking, Article 47 of the Law on Capital Markets, Articles 17, 27 and 55 of the Law on Commodity Futures Trading, and Article 41 and Article 42 of the Law on Sharia Banking. Second, Law No. 23 of 2014 on Local Government repealed in Law No. 5 of 1962 on Regional Companies Articles 157, 158 (2) and (9), and 159 of Law No. 28 of 2009 on Regional Taxes and Regional Taxes, Articles 1 Number 4, 314-412, and 418-421 of Law No. 17 of 2014 on the Parliamentary Bodies.

\section{THE FUTURE OF INDONESIA'S OMNIBUS LAW: A CONTINUING RELEVANCE}

From the practices in the countries already described, omnibus law becomes an approach or method in a process of law-making. With omnibus law, it is possible to harmonize, synchronize, correct, and simplify simplification. Through this method, a law is very likely to consist of various substances and is multi-sectoral. We can also see this in the omnibus law, such as the Work Creation Law, which will repeal about 79 Laws, 1,244 articles, and substantively include 11 clusters. These clusters include Land Simplification, Investment Requirements, Employment, SME Facilities and Protection, Ease of Business, Research and Invoice Support, Government Administration, Imposition of Sanctions, Land Management, Facilities of Government Projects, and Special Economic Zones.

The Job Creation Law has received much rejection because it is considered very detrimental to the community and the environment and only benefits capital owners. It is necessary to consider the process of forming omnibus law as it is not drafted to reckon multi perspectives. For example, the creation of this law aims to encourage investment but exempt environmental protection, labor rights, conditions in an area, and other aspects as philosophical considerations of the many laws that will be affected once it has been enacted. ${ }^{44}$

44 Jimmy Z. Usfunan, "Menata Undang-Undang dengan Omnibus Law" online: 〈https://www. hukumonline.com/berita/baca/lt5a28elbb9lcc6/menata-undang-undang-dengan-omnibus-law-oleh-jimmy-z-usfunan?page $=2>$ at 2 . 
Given Vietnam's success in adopting omnibus law with the absence of the omnibus law method in its legislative draft guidelines, it asserts that Indonesia can take the same pathway. In Law No. 12 of 2011, as amended by Law No. 15 of 2019 on Legislative Draftings, it is necessary to formulate how to form a law with omnibus law. To accommodate the arrangements on omnibus law, it needs to revise the current Legislative Draftings Law.

Another highlighted issue and not less critical about the institution is when we reckon omnibus law on the Job Creation Bill, which contains quite a few clusters. This situation will be difficult and less effective than when this omnibus law is handed over to ministries or boards. Therefore, it is necessary to have a single special institution in formulating omnibus law. It considers omnibus law a law containing the substance to affirm previous legal norms disseminated in several laws. The arrangement should be carried out with great care by excluding the sectoral procedure. ${ }^{45}$

The realization of the establishment of special legislation institutions has been explicitly implemented through the revision of Law No. 12 of 2011 on Legislative Draftings. Law has mandated the formation of the body in Law No. 15 of 2019 on the amendment of Law No. 12 of 2011 on Legislative Draftings. Article 99A states that before forming the ministry or institution responsible for the formulation of government affairs in legislation. This minister conducts government affairs in law to continue to carry out the function of law-making. "

This agency will later analyze, coordinate, and streamline all technical rules formed to implement the draft law. This is because automatically, there will be many technical regulations synchronized both in government regulations, presidential regulations, ministerial regulations, and local regulations. It will be free in the application of omnibus law when its implementation rules are not implemented. This will even legitimize hyperregulation. By taking into account omnibus law enforcement in the United States, the method uses in creating a single policy package. For example, it is related to investment that regulates investment procedures and licensing procedures, labor, land transfer procedures, and many other aspects. As a result, the rights and obligations of investors are set holistically into one legal document. Due to many articles in the omnibus law, it is not easy to realize in Indonesia. Indonesia has a hierarchy of laws and regulations, so one issue can be seen in various regulations, both at the central and regional levels. ${ }^{46}$

Besides, Indonesia needs to project a limited use of omnibus law. This experience has been applied in Indonesia. One of the law's formation patterns is to combine 2 or 3 even more cargo material set out in the 1945 Constitution. For example, Law No. 23 of 2014 on Local Government, Law No. 17 of 2014 on the Parliamentary Bodies. As for the incorporation of organized substances still belongs to one big topic (limited). This limited law omnibus method is a relatively safer mechanism and is very practically possible. This is because the executive body consists of various ministries or institutions,

\footnotetext{
${ }^{45}$ Media Indonesia, "Janji Presiden Bentuk Pusat Legislasi Nasional Ditagih" online: ‘https://mediaindonesia.com/ $\mathrm{read} /$ detail/267464-janji-presiden-bentuk-pusat-legislasi-nasional-ditagih».

46 Jimmy Z. Usfunan, supra note 44.
} 
each of which has its duties and functions based on its fields. Similarly, Indonesia's House consists of several commissions. The presence of a limited omnibus law will facilitate determining which ministry will be the leading sector in law formation. The same goes for determining the House commission that deals with it, rather than forming an unlimited omnibus law. ${ }^{47}$

In the future, the House and the Government should maximize limited omnibus law methods, starting with national legislative programs based on major themes. Furthermore, it is followed by a revision of the law that is considered no longer in line with the need to adapt to the development of factual circumstances. Of course, this process is implemented while still considering the values of justice and society's legal needs when the law is drafted. By taking into account omnibus law in the Job Creation Act, many cross-field arrangements will undoubtedly have the potential for conflict of interest in the formation of omnibus law. There are five critical recommendations in ensuring that omnibus law contains social justice. First, openness, prudence, and community participation. ${ }^{48}$ Second, a wide range of outreach efforts, especially for officials and parties involved in the bill's substance, legal practitioners, and academics. ${ }^{49}$ Third, the House's deliberation process must be transparent by taking into account input from parties related to the bill, not rushing into its deliberations. ${ }^{50}$ Fourth, considering a sufficient period, the omnibus law comes into effect. ${ }^{51}$ and Fifth, considering the validity of existing laws. ${ }^{52}$ Thus, as the legislative body, the House and the Government should put forward political interests or particular groups. Instead, both must aspire to public participation in forming the legislation.

\section{CONCLUSION}

Omnibus law in the United States and Ireland shows the contribution to ushering hyperregulation symptoms that are vulnerable and hamper economic development. In practice, omnibus law in these countries is arranged with minimal public participation with the limited debate and most likely exchange changing political interests. Then substance and technique in forming the legislation in such countries succeeded in applying omnibus law because it discusses a single subject clause, different from in Indonesia. The above comparison needs to be adjusted to the Indonesian context to enact the omnibus law. In so doing, it remains to consider public participation despite the importance of the sound omnibus bill formed under the omnibus method.

\footnotetext{
47 Ibid.

48 University of Indonesia Law School, "Tiga Guru Besar Ini Beri Masukan Soal Omnibus Law" online: 〈https://law.ui.ac.id/v3/tiga-guru-besar-ini-beri-masukan-soal-omnibus-law/〉.

49 Ibid.

50 Ibid.

Ibid.

52 Ibid.
} 


\section{ACKNOWLEDGMENTS}

The authors thank the journal's editorial board members and anonymous reviewers for the suggestions and feedback. Also, they thank the Center for Pancasila and Constitutional Studies (PUSKAPSI) at the Faculty of Law, the University of Jember, for supporting this publication.

\section{COMPETING INTERESTS}

The authors declare that they have no competing interests.

\section{REFERENCES}

Anggono, Bayu Dwi, "Omnibus Law Sebagai Teknik Pembentukan Undang-Undang: Peluang Adopsi dan Tantangannya dalam Sistem Perundang-Undangan Indonesia" (2020) 9:1 Jurnal Rechts Vinding: Media Pembinaan Hukum Nasional 17.

-_- " "Perkembangan Jenis, Hierarki dan Materi Muatan Peraturan Perundang-undangan: Permasalahan dan Solusi" (2018).

Busroh, Firman Freaddy, "Konseptualisasi Omnibus Law dalam Menyelesaikan Permasalahan Regulasi Pertanahan" (2017) 10:2 Arena Hukum 227-250.

Cabinet Secretariat, "RUU Omnibus Law: Upaya Perkuat Perekonomian Nasional melalui Penciptaan Lapangan Kerja dan Fasilitas Perpajakan,” online: 〈https://setkab.go.id/ ruu-omnibus-law-upaya-perkuat-perekonomian-nasional-melalui-penciptaanlapangan-kerja-dan-fasilitas-perpajakan/>.

Chairunnisa, Ninis, "Pengamat Hukum: Banyak Negara Kapok Pakai Omnibus Law" online: 〈https://nasional.tempo.co/read/1310811/pengamat-hukum-banyak-nega rakapok-pakai-omnibus-law>.

Chronicle, "Ireland publishes omnibus bill of emergency laws in case of no-deal Brexit" online: 〈https://www.chronicle.gi/ireland-publishes-omnibus-bill-emergency-lawscase-no-deal-brexit/>.

Detik News, "Selain Indonesia, Negara-negara Ini Juga Terapkan Omnibus Law" online: detiknews 〈https://news.detik.com/berita/d-4868547/selain-indonesia-negaranegara-ini-juga-terapkan-omnibus-law>.

Doing Business, "Doing Business 2020" online: 〈https:/www.doingbusiness.org/en/ reports/global-reports/doing-business-2020>.

Duhaime, "Omnibus Bill Definition" online: 〈http:/www.duhaime.org/LegalDictionary/ O/OmnibusBill.aspx>.

Fitryantica, Agnes, "Harmonisasi Peraturan Perundang-Undangan Indonesia melalui Konsep Omnibus Law" (2019) 6:3 Gema Keadilan 300-316.

Gluck, Abbe R, Anne Joseph O'Connell \& Rosa Po, "Unorthodox Law-making, Unorthodox Rulemaking" (2015) 115 Colum L Rev 1789. 
Hernawati, R A S \& Joko Trio Suroso, "Kepastian Hukum dalam Hukum Investasi di Indonesia Melalui Omnibus Law" (2020) 4:1 Jurnal Ilmiah Manajemen, Ekonomi, \& Akuntansi) 392-408.

House of Oireachtas, "Bills o Acts of the Oireachtas - Houses of the Oireachtas" online: 〈https://www.oireachtas.ie/en/bills〉.

- _ _ _ _ _ _ _ - How laws are made - Houses of the Oireachtas" online: 〈https://www. oireachtas.ie/en/visit-and-learn/how-parliament-works/how-laws-are-made).

Hukumonline, "Lima Langkah Penataan Regulasi untuk Pemerintahan Jokowi Jilid II" online: hukumonline.com 〈https:/www.hukumonline.com/berita/baca/lt5db95c405c ce2/lima-langkah-penataan-regulasi-untuk-pemerintahan-jokowi-jilid-ii/>.

___ _ "Menelusuri Asal-Usul Konsep Omnibus Law" online: 〈https://www.h ukumonline.com/berita/baca/lt5e2cle4de97la/menelusuri-asal-usul-konsepomnibus-law>.

Indrati, Maria Farida, "Ilmu Perundang-Undangan: Jenis, Fungsi, dan Materi Muatan" (2007) Yogyakarta: Kanisius.

_________ "Omnibus Law, UU Sapu Jagat?" online: Kompas.id 〈https://kompas.id/baca/opini/2020/01/04/omnibus-law-uu-sapu-jagat/〉.

Isra, Saldi, Pergeseran Fungsi Legislasi: Menguatnya Legislasi Parlementer dalam Sistem Presidensial di Indonesia (Jakarta: Rajawaali press, 2011).

Jimly School, "UU Omnibus Law Penyederhanaan Legislasi dan Kodifikasi Administrasi” online 〈https://www.jimlyschool.com/baca/34/uu-omnibus-omnibus-lawpenyederhanaan-legislasi-dan-kodifikasiadministratif>.

Jimmy Z. Usfunan, "Menata Undang-Undang dengan Omnibus Law" online: 〈https://www. hukumonline.com/berita/baca/lt5a28elbb9lcc6/menata-undang-undangdengan-omnibus-law-oleh--jimmy-z-usfunan?page=2>.

Kanal24, "Patrick Keyzer: Omnibus Law Menambah Kompleksitas Hukum Indonesia", online: 〈http://kanal24.co.id/read/patrick-keyzer-omnibus-law-menambahkompleksitas-hukum-indonesia>.

Kompas Cyber Media, "Naskah Lengkap Pidato Presiden Joko Widodo dalam Pelantikan Periode 2019-2024" online: 〈https://nasional.kompas.com/jeo/naskah-lengkap-pidatopresiden-joko-widodo-dalam-pelantikan-periode-2019-2024〉.

________ _ _ Rekomendasi Jember untuk Penataan 'Obesitas Regulasi' di Indonesia" online: 〈https://nasional.kompas.com/read/2017/11/12/17412311/rekomendasijember-untuk-penataan-obesitas-regulasi-di-indonesia.

Krutz, Glen Stuart, "Explaining Institutional Change: The Rise and Impact of Omnibus Legislating" (2000).

Kurniawan, Fajar, "Problematika Pembentukan RUU Cipta Kerja Dengan Konsep Omnibus Law" (2020) 5:1 Jurnal Panorama Hukum 63-76.

Massicotte, Louis, "Omnibus Bills in Theory and Practice" (2013) 36:1 Canadian Parliamentary Review 13-17. 
Mayasari, Ima, "Menggagas Omnibus Law" online: kumparan 〈https://kumparan.com/ drima-mayasari-m-h/menggagas-omnibus-law-1542018891459839175>.

Media Indonesia, “Janji Presiden Bentuk Pusat Legislasi Nasional Ditagih” online: 〈https:// mediaindonesia.com/read/detail/267464-janji-presiden-bentuk-pusat-legislasinasional-ditagih>.

, "Obesitas Regulasi” online: 〈https://mediaindonesia.com/podiums/detail _podiums/1671-obesitas-regulasi>.

Republika, "Peringkat Kemudahan Bisnis di Indonesia Belum Naik" online: 〈https://republika.co.id/share/pzv8gg383〉.

Sindonews, "Serikat PekerjaTolak Omnibus Law" online: 〈https://nasional.sindonews.com/ berita/1509229/16/serikat-pekerjatolak-omnibus-law〉.

Suriadinata, Vincent, "Penyusunan Undang-Undang di Bidang Investasi: Kajian Pembentukan Omnibus Law Di Indonesia" (2019) 4:1 Refleksi Hukum: Jurnal Ilmu Hukum 115132.

Susskind, Richard E, The Susskind Interviews: Legal Experts in Changing Times (Sweet \& Maxwell, 2005).

Torontosun, "Omnibus Bills in Hill History," online: Toronto Sun 〈https://torontosun. com/2012/06/18/omnibus-bills-in-hill-history>.

University of Indonesia Law School, "Tiga Guru Besar Ini Beri Masukan Soal Omnibus Law" online: 〈https://law.ui.ac.id/v3/tiga-guru-besar-ini-beri-masukan-soal-omnibus -law/s.

World Bank, "The World Bank DataBank" (2018).

World Economic Forum, "World Economic Forum Reports," online: 〈https://www.weforum. org/reports/>. 
336 | Omnibus Law in Indonesia: A Comparison to the United States and Ireland

This page intentionally left blank 